\title{
GMR
}

\section{Genetic diversity of native populations of Croton tetradenius Baill. using ISSR markers}

\author{
C.S. Almeida-Pereira ${ }^{1}$, A.V.C. Silva ${ }^{2}$, R.P. Alves ${ }^{1}$, R.B. Feitosa-Alcantara ${ }^{1}$, \\ M.F. Arrigoni-Blank ${ }^{1}$, S.V. Alvares-Carvalho ${ }^{1}$, T.S. Costa ${ }^{2}$, L.A.S. White ${ }^{1}$, \\ V.S. Pinto ${ }^{1}$, T.S. Sampaio ${ }^{1}$ and A.F. Blank ${ }^{1}$ \\ ${ }^{1}$ Laboratório de Recursos Genéticos Vegetais e Óleos Essenciais, \\ Departamento de Engenharia Agronômica, \\ Universidade Federal de Sergipe, São Cristóvão, SE, Brasil \\ ${ }^{2}$ Laboratório de Biologia Molecular, Embrapa Tabuleiros Costeiros, \\ Aracaju, SE, Brasil \\ Corresponding author: A.F. Blank \\ E-mail: afblank@ufs.br \\ Genet. Mol. Res. 16 (2): gmr16029602 \\ Received January 11, 2017 \\ Accepted April 10, 2017 \\ Published May 18, 2017 \\ DOI http://dx.doi.org/10.4238/gmr16029602
}

Copyright $(2017$ The Authors. This is an open-access article distributed under the terms of the Creative Commons Attribution ShareAlike (CC BY-SA) 4.0 License.

ABSTRACT. Brazil has about 300 Croton species in different types of
vegetation. Croton tetradenius Baill., which is endemic to the Northeast
region and predominant in the Caatinga vegetation, stands out among the
several species of this genus. Considering the importance of knowing
the genetic variability of a species, the objective of this study was to
analyze the genetic diversity of the genotypes of natural populations of
C. tetradenius in the State of Sergipe, using ISSR molecular markers.
Forty individuals were sampled in four natural populations of the State
of Sergipe, Brazil. Thirteen primers were used for DNA amplification
using ISSR-PCR, totaling 77 amplified fragments, of which $94.8 \%$
were polymorphic. Results of the cluster analysis obtained by the
Jaccard's similarity index, using the UPGMA method, resulted in
the formation of six distinct clusters. Analysis of molecular variance
(AMOVA), used to estimate the genetic variability among populations,
revealed significant genetic variance $(\mathrm{P}<0.01)$ between and within the

Genetics and Molecular Research 16 (2): gmr16029602 
studied populations, and most of the genetic diversity was found (87\%) within populations. According to the Jaccard's similarity index, none of the studied plants was genetically identical. CTE210 and CTE305 presented high similarity index (0.76), while CTE105 presented low similarity index $(<0.16)$ with all related individuals. ISSR markers were efficient and allowed the formation of a molecular profile, and had sufficient polymorphism to estimate the genetic variability between the accessions of the studied populations.

Key words: Croton tetradenius; Conservation strategies; Genetic diversity; ISSR

\section{INTRODUCTION}

Croton tetradenius Baill. is an endemic species of the Northeast region of Brazil, found in the Caatinga vegetation in the States of Alagoas, Bahia, Ceará, Paraíba, Pernambuco, Rio Grande do Norte, and Sergipe (Carneiro-Torres, 2009). It is disseminated in areas of sandy or stony soil, in shaded and humid environments (Lucena, 2009; Silva et al., 2009). It is popularly known as "caatinga-de-bode", "zabelê", "velandinho", "barba-de-bode", and has delicate leaves and a well-accented mentholated aroma (Lucena, 2009).

The genus Croton is one of the largest representatives of the family Euphorbiaceae (Webster, 1993). Some species of the genus Croton have been distinguished by their diverse pharmacological properties (Fontenelle et al., 2008). Despite the great diversity and significant importance of this genus, taxonomy, ecology, genetics, phytochemistry, and ethnobotany studies are still necessary, as well as the promotion of product development, and in situ and ex situ conservation strategies (Alves et al., 2012). The development of an essential oil-based formulation of $C$. tetradenius with biological potential was reported for the first time using the deposit of a patent (Blank et al., 2017).

The economic potential of medicinal and aromatic plants has contributed to the significant growth of the interest for germplasm characterization and conservation (Souza, 2015). Germplasm characterization allows the insertion of materials of interest in breeding programs and serves as a basis for the design of conservation strategies. The genetic characterization of natural populations using molecular markers has been reported in several studies (Estopa et al., 2006; Bertoni et al., 2010; Giustina et al., 2014; Soares et al., 2016).

Several molecular markers are available in the market, and the knowledge on the properties and applications of the species is necessary to choose the appropriate marker according to the profile of the study of interest (Souza, 2015).

Molecular markers, which are identifiable DNA sequences specific to the genome, are useful tools in the exploration of genetic diversity and provide information on genetic variability by eliminating possible environmental effects (Soares et al., 2016).

ISSR (inter-simple sequence repeat) markers were developed by Zietkiewicz et al. (1994) and are based on the amplification of regions between DNA adjacent microsatellite sequences via PCR (polymerase chain reaction). For being dominant markers, prior knowledge on the genome is not required (González et al., 2002). Moreover, ISSR markers have a high degree of polymorphism, high reproducibility, when compared with other markers, and can achieve results in a timely and cost-effectively manner (Borba et al., 2005). Therefore, ISSR

Genetics and Molecular Research 16 (2): gmr16029602 
markers are very useful in studies that aim at determining the genetic distance between parents, as well as the performance of the hybrids for the construction of genetic linkage maps, and for the characterization of accessions and cultivars of several species (Santos et al., 2013; Soares et al., 2016).

ISSR markers are more reproducible than other dominant markers, such as random amplified polymorphic DNA(RAPD). The reproducibility of this marker is associated with two characteristics that provide high specificity to the ISSR primers: high annealing temperature and design based on the microsatellite regions, which makes ISSR semi-arbitrary markers (Sandes et al., 2016).

Several studies on genetic diversity in medicinal plants have been carried out using ISSR molecular markers, such as those in Croton (Lira Neto, 2011; Scaldaferri et al., 2014; Rocha et al., 2016), in Varronia curassavica Jacq. (Brito et al., 2016), in Capparis spinosa L. (Liu et al., 2015), in Rheum (Tabin et al., 2016), in Withania somnifera (Khan and Shah, 2016), and in Panax stipuleanatus Tsai (Trieu et al., 2016).

The objective of this study was to analyze the genetic diversity of plants from four natural populations of $C$. tetradenius in the State of Sergipe, using ISSR molecular markers.

\section{MATERIAL AND METHODS}

\section{Plant material}

Three young leaves were collected from plants from four natural populations of Croton tetradenius in the municipalities of Lagarto (Povoado Antônio Conselheiro and Povoado Tiradentes), Porto da Folha and Poço Redondo, in the State of Sergipe, totaling 40 individuals (Figure 1 and Table 1). To prevent oxidation of the collected samples, leaves were wrapped in sterile gauze and stored on ice, and frozen at $-80^{\circ} \mathrm{C}$. Subsequently, the plant material was lyophilized in a LioTop (L101) and stored in a desiccator containing silica gel until DNA extraction.

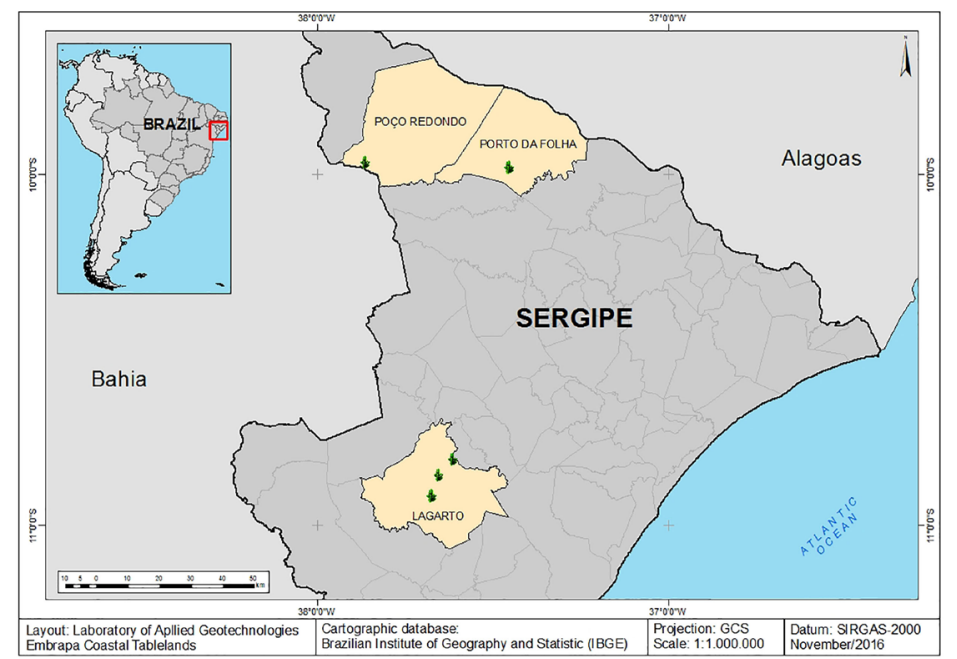

Figure 1. Map with the locations of the Croton tetradenius plants collected from natural populations in the State of Sergipe, Brazil.

Genetics and Molecular Research 16 (2): gmr16029602 
Table 1. Identification of Croton tetradenius plants from four native populations, in the State of Sergipe, Brazil.

\begin{tabular}{|c|c|c|c|c|}
\hline Plant code & Pop. & $\mathrm{N}$ & Origin (Municipality, village) & Georeferenced information \\
\hline CTE101-110 & 1 & 10 & $\begin{array}{l}\text { Lagarto, } \\
\text { Tiradentes }\end{array}$ & 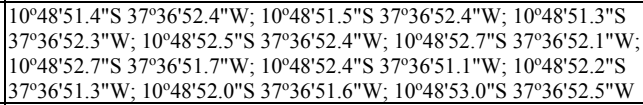 \\
\hline CTE201-210 & 2 & 10 & $\begin{array}{l}\text { Porto da Folha, } \\
\text { Lagoa do Rancho }\end{array}$ & 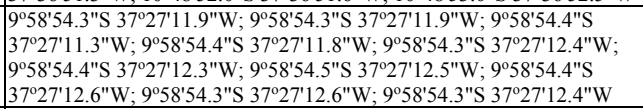 \\
\hline CTE301-310 & 3 & 10 & $\begin{array}{l}\text { Poço Redondo, } \\
\text { Serra da Guia }\end{array}$ & 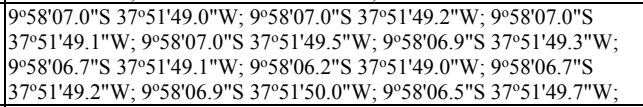 \\
\hline CTE401-410 & 4 & 10 & $\begin{array}{l}\text { Lagarto, } \\
\text { Antônio Conselheiro }\end{array}$ & 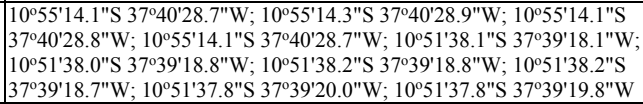 \\
\hline
\end{tabular}

Pop. $=$ population; $\mathrm{N}=$ number of plants.

\section{DNA extraction and ISSR-PCR amplification}

The previously lyophilized young leaves were subjected to DNA extraction, using approximately $1 \mathrm{~g}$ fresh leaves for each sample, based on the method described by Doyle and Doyle (1990), modified by Alzate-Marin et al. (2009). DNA was quantified using the Nanodrop 2000c spectrophotometer (Thermo Scientific, USA). After dilutions at the desired concentrations, samples were stored at $-20^{\circ} \mathrm{C}$ for further use in the PCRs.

The ISSR primers used to estimate the genetic diversity of the 40 individuals of $C$. tetradenius were obtained from the University of British Columbia, Vancouver, Canada (Table 2).

Thirteen primers were selected for DNA amplification using the ISSR-PCR. Each reaction was performed in a pre-sterile $12-\mu \mathrm{L}$ microtube containing $1 \mu \mathrm{L}$ genomic DNA $(5 \mathrm{ng} /$ $\mu \mathrm{L}), 0.2 \mu \mathrm{L}$ recombinant Taq polymerase from Thermus aquaticus, expressed in Escherichia coli (Ludwig Biotec, Brazil) $(5 \mathrm{U} / \mu \mathrm{L}), 2 \mu \mathrm{L} 10 \mathrm{X}$ buffer $(100 \mathrm{mM}$ Tris- $\mathrm{HCl}, \mathrm{pH} 8.5,500 \mathrm{mM}$ $\mathrm{KCl}), 0.6 \mu \mathrm{L} \mathrm{MgCl}_{2}(50 \mathrm{mM})$ (Ludwig Biotec), $0.4 \mu \mathrm{L}$ dNTP $(2.5 \mathrm{mM}), 2.0 \mu \mathrm{L}$ primer $(25.0$ pmol), and $5.8 \mu \mathrm{L}$ autoclaved ultrapure water.

DNAs were amplified using the thermocycler ProFlex PCR System (Thermo Fisher Scientific, Applied Biosystems, Foster City, CA, USA) programmed with the following protocol: an initial denaturation at $95^{\circ} \mathrm{C}$ for $5 \mathrm{~min}$, followed by 35 amplification cycles; denaturation at $94^{\circ} \mathrm{C}$ for $40 \mathrm{~s}$; annealing at different temperatures for $1 \mathrm{~min}$ (depending on the optimum primer temperature); extension at $72^{\circ} \mathrm{C}$ for $1 \mathrm{~min}$; and a final extension at $72^{\circ} \mathrm{C}$ for $7 \mathrm{~min}$.

Amplification products were subjected to horizontal electrophoresis on $2.0 \%$ agarose gel and then stained with ethidium bromide $(0.5 \mu \mathrm{L} / \mathrm{mL})$, visualized under ultraviolet light, and photodocumented in Gel Doc L-pix (Loccus Biotecnologia, Cotia, SP, Brazil). Molecular weights were estimated using a 1-kb scale for each primer (Ludwig Biotec).

\section{Data analysis}

By analyzing the agarose gels, a binary matrix was obtained based on the presence (1) and absence ( 0 ) of bands for all selected primers. The binary data were used in all analyses.

Genetic similarities among individuals were obtained using the Jaccard's similarity index (Jaccard, 1908). For plant clustering, based on the genetic similarity, the unweighted 
pair group method with arithmetic mean (UPGMA) was used to construct the dendrogram, with the aid of the NTSYS-pc 2.0 software (Rohlf, 2001). The values of correlation and stress, polymorphic information content (PIC), and expected heterozygosity $\left(H_{\mathrm{E}}\right)$ under the HardyWeinberg equilibrium (HWE) were also estimated using the GENES program (Cruz, 2001).

Percentage of polymorphic bands (PPB), number of observed alleles, effective number of alleles $\left(N_{\mathrm{E}}\right)$, Nei's genetic diversity $(\mathrm{h})$, and Shannon index were estimated using the Genalex 6.5 software (Peakall and Smouse, 2012).

\section{RESULTS}

By the UPGMA dendrogram, based on the Jaccard's similarity index, six main clusters were formed using a mean distance of approximately 0.44 (Figure 2). Cluster I is composed mostly of natural individuals from the same geographical location (Lagarto, Antônio Conselheiro village), except for CTE101 (Lagarto, Tiradentes village) and CTE207 (Porto da Folha, Lagoa do Rancho village). Cluster II, the largest representative, consisted of 27 individuals from all the studied populations, emphasizing that all the individuals that represent the population 03 (Poço Redondo, Serra da Guia) were clustered together.

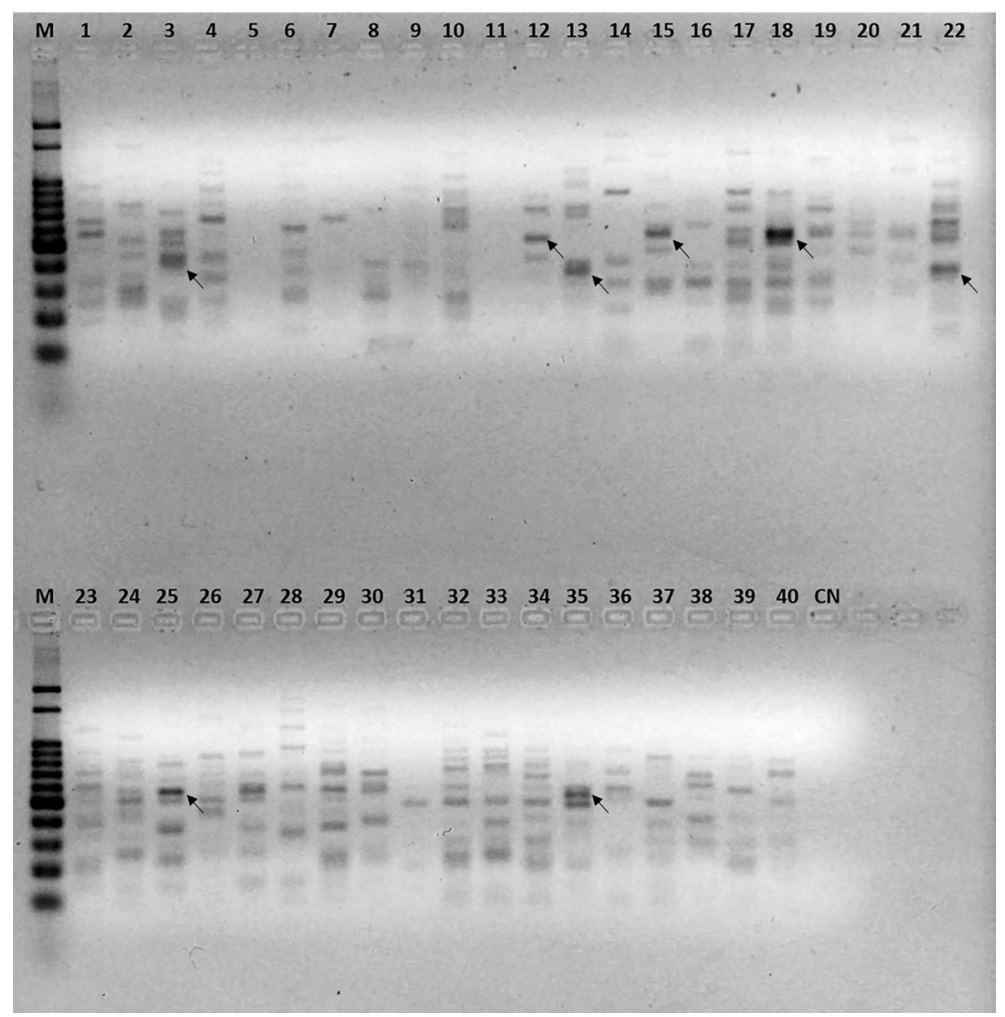

Figure 2. Agarose gels showing the electrophoretic profiles of the inter-simple sequence repeat markers amplified using the primer 842 in 40 Croton tetradenius plants from four native populations, in the State of Sergipe, Brazil. (Lane M: 1-kb molecular weight marker; lanes 1 to 10: Population 1; lanes 11 to 20: Population 2; lanes 21 to 30: Population 3; lanes 31 to 40: Population 4; CN: negative control). Arrows indicate specific bands. 
Thirteen ISSR primers were used for the study on the genetic variability of the 40 samples of C. tetradenius, totaling 77 amplified fragments, of which $94.8 \%$ were polymorphic. The number of amplified fragments ranged from 3 to 11 bands per primer, totaling a mean of 5.9 bands per primer (Table 2).

Table 2. Annealing temperature, sequence, and amplified products used for genetic diversity analysis in Croton tetradenius plants from four native populations, in the State of Sergipe, Brazil.

\begin{tabular}{|c|c|c|c|c|c|c|}
\hline Primer name & Sequence $\left(5^{\prime}-3^{\prime}\right)$ & Length (bp) & Annealing temperature $\left({ }^{\circ} \mathrm{C}\right)$ & Total bands & Polymorphic bands & Polymorphism (\%) \\
\hline UBC851 & GTG TGT GTG TGT GTG TYG & $300-900$ & 49.2 & 7 & 6 & 85.7 \\
\hline UBC817 & CAC ACA CAC ACA CAC AA & $300-1250$ & 54.8 & 5 & 5 & 100.0 \\
\hline UBC812 & GAG AGA GAG AGA GAG AA & $300-1000$ & 54.8 & 7 & 7 & 100.0 \\
\hline UBC816 & CAC ACA CAC ACA CAC AT & $300-800$ & 54.8 & 6 & 6 & 100.0 \\
\hline UBC842 & GAG AGA GAG AGA GAG AYG & $200-1500$ & 58.8 & 10 & 10 & 100.0 \\
\hline UBC864 & ATG ATG ATG ATG ATG ATG & $500-900$ & 50.8 & 5 & 4 & 80.0 \\
\hline UBC888 & BDB CAC ACA CAC ACA CA & $200-700$ & 56.4 & 5 & 5 & 100.0 \\
\hline UBC890 & VHV GTG TGT GTG TGT GT & $400-700$ & 56.4 & 4 & 4 & 100.0 \\
\hline UBC809 & AGA GAG AGA GAG AGA GG & $300-800$ & 57.2 & 3 & 2 & 66.6 \\
\hline UBC 810 & GAG AGA GAG AGA GAG AT & $300-800$ & 54.8 & 5 & 4 & 80.0 \\
\hline UBC811 & GAG AGA GAG AGA GAG AC & $400-700$ & 46.8 & 3 & 3 & 100.0 \\
\hline UBC 848 & CAC ACA CAC ACA CAC ARG & $200-1000$ & 58.8 & 11 & 11 & 100.0 \\
\hline UBC815 & CTC TTC ТCT СТC ТCT CTG & $400-1500$ & 47.6 & 6 & 6 & 100.0 \\
\hline
\end{tabular}

The similarity matrix based on the Jaccard's similarity index among the $40 \mathrm{C}$. tetradenius showed a minimum value of 0.01 between the plants CTE105 and CTE210, and a maximum value of 0.76 between the plants CTE210 and CTE305. Greater genetic diversity was observed between two plants of different populations, CTE105 (Lagarto, Tiradentes village) and CTE210 (Porto da Folha, Lagoa do Rancho village), with a similarity index of 0.01. Conversely, CTE210 (Porto da Folha, Lagoa do Rancho village) and CTE305 (Poço Redondo, Serra da Guia), which also belong to different populations, presented the highest genetic diversity, with a similarity index of 0.76 (Table 3).

The reliability of the results was verified by the values of stress $(0.0245)$, and correlation $(0.997)$ for the 40 C. tetradenius studied plants, which confirmed the stability of the number of selected primers and the number of obtained fragments.

Genetic variability indices, such as $H_{\mathrm{E}}$ and the Shannon index, presented low means, 0.30 and 0.45 , respectively, indicating low levels of genetic diversity (Table 4).

The clustering between individuals by the Jaccard's similarity index, using the UPGMA method, resulted in six distinct clusters: cluster I (CTE101, CTE207, CTE402, CTE403, CTE404, CTE405, CTE407, CTE408, and CTE410); cluster II (CTE102, CTE103, CTE104, CTE106, CTE108, CTE109, CTE110, CTE201, CTE202, CTE204, CTE205, CTE206, CTE208, CTE209, CTE210, CTE301, CTE302, CTE303, CTE304, CTE305, CTE306, CTE307, CTE308, CTE309, CTE310, CTE406, and CTE409); cluster III (CTE107); cluster IV (CTE203); cluster V (CTE401); and cluster VI (CTE105) (Figure 3).

Analysis of molecular variance (AMOVA), used to estimate the genetic variability among populations, revealed significant genetic variance $(\mathrm{P}<0.01)$ between and within the studied populations, being most of the genetic diversity found within the populations (87\%) (Table 5).

Genetics and Molecular Research 16 (2): gmr16029602 


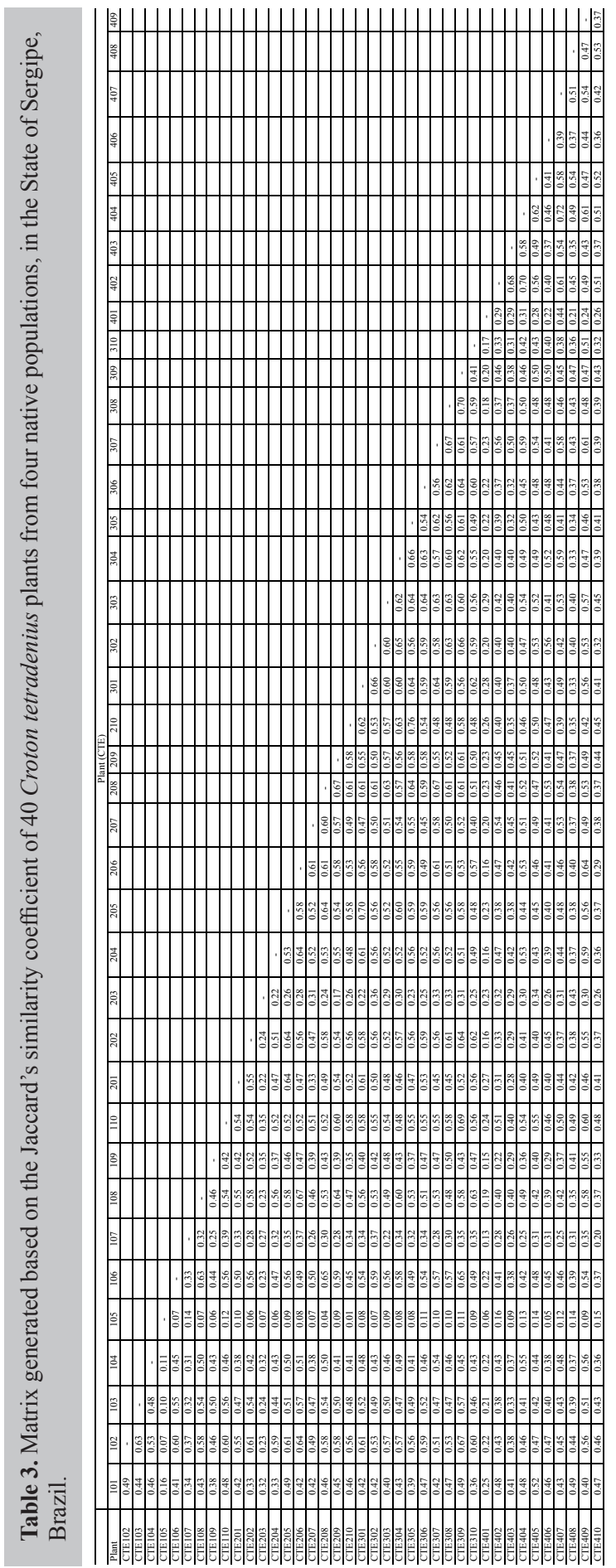

Genetics and Molecular Research 16 (2): gmr16029602 
Table 4. Number of observed alleles $(\mathrm{N})$, effective number of alleles $\left(N_{\mathrm{E}}\right)$, Shannon's index $(\mathrm{I})$, expected $\left(H_{\mathrm{E}}\right)$ and observed $\left(H_{\mathrm{O}}\right)$ heterozygosities, and polymorphic information content (PIC) for the four native populations of Croton tetradenius, obtained by ISSR markers.

\begin{tabular}{l|c|c|c|c|c|c|c}
\hline Population & $\mathrm{N}^{\circ}$ of individuals & $\mathrm{N}$ & $N_{\mathrm{E}}$ & $\mathrm{I}$ & $H_{\mathrm{E}}$ & $H_{\mathrm{O}}$ & PIC \\
\hline Pop. 1 & 10 & 1.78 & 1.58 & 0.49 & 0.33 & 0.37 & 0.23 \\
\hline Pop. 2 & 10 & 1.48 & 1.44 & 0.39 & 0.26 & 0.29 & 0.17 \\
\hline Pop. 3 & 10 & 1.85 & 1.58 & 0.50 & 0.33 & 0.37 & 0.24 \\
\hline Pop. 4 & 10 & 1.75 & 1.45 & 0.42 & 0.27 & 0.31 & 0.22 \\
\hline Total & 40 & 1.71 & 1.51 & 0.45 & 0.30 & 0.33 & 0.22 \\
\hline
\end{tabular}

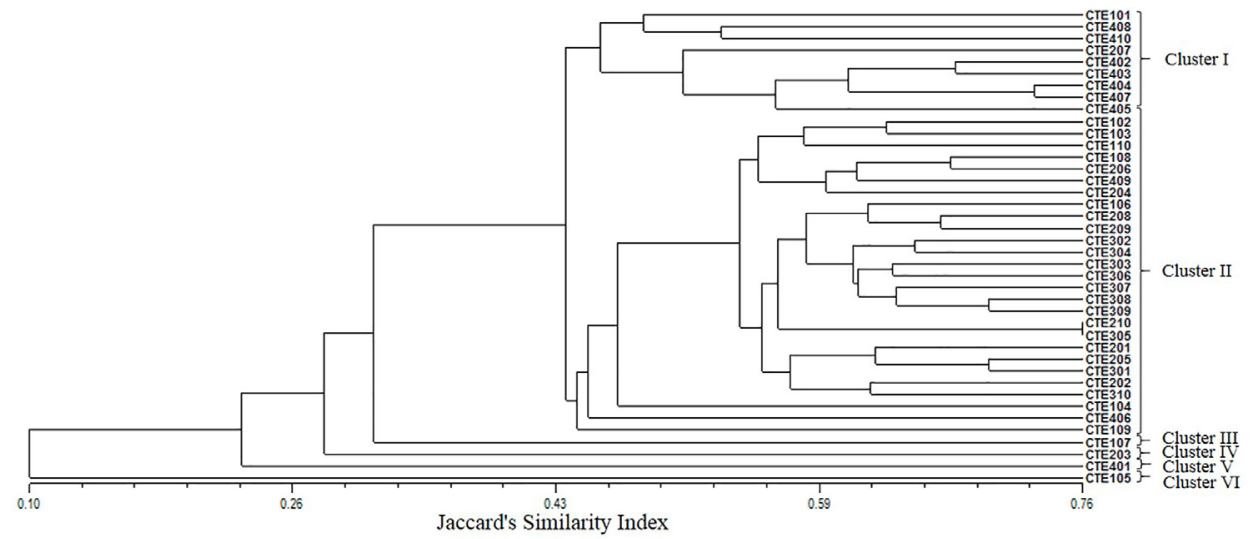

Figure 3. Dendrogram generated by the unweighted pair group method with arithmetic mean analysis (UPGMA) of Jaccard's similarity indices for 40 Croton tetradenius plants from four populations, in the State of Sergipe, Brazil.

Table 5. Analysis of molecular variance of 40 Croton tetradenius plants from four native populations, in the State of Sergipe, Brazil.

\begin{tabular}{l|c|c|c|c|c}
\hline Source of variation & Degrees of freedom & Sum of squares & Mean squares & Components of variation & $\%$ of variation \\
\hline Among populations & 3 & 98.85 & 32.95 & 2 & 13 \\
\hline Within populations & 36 & 465.80 & 12.94 & 12.93 & 87 \\
\hline Total & 39 & 564.65 & - & 14.94 & 100 \\
\hline
\end{tabular}

\section{DISCUSSION}

Considering the set of parameters of diversity evaluated, the genetic variability among the studied $C$. tetradenius individuals was moderate.

The primer UBC 848 presented the highest number of fragments (11), resulting in $100 \%$ polymorphism. The low percentage of monomorphic primers found in this study demonstrates the efficiency of the ISSR molecular marker.

Many studies have proved the effectiveness of this marker in articles on genetic diversity and characterization of accessions between and within populations, such as those with Ocimum basilicum (Aghaei et al., 2012), Pitcairnia flammea (Souza-Sobreira et al., 2015), Croton heliotropiifolius (Rocha et al., 2016), Erythrina velutina (Souza et al., 2016), and Varronia curassavica (Brito et al., 2016). 
Values different from zero were expected in relation to the mean value of genetic diversity (0.30) and to the Shannon index (0.45), since under natural conditions, the HardyWeinberg equilibrium is not expected. This is because individuals are likely to incorporate new alleles using crosses, and lose alleles using genetic drift (Silva et al., 2012). The Shannon index may vary from 0 to 1 , and lower genetic diversity is represented by values closer to zero (Silva et al., 2015). Several studies on natural populations indicate the percentage of the polymorphic locus as an important measure of genetic diversity; however, despite being commonly used, a variation in these values is observed (Soares et al., 2016). According to Nei (1987), the proportion of polymorphic locus is not a significant measure of the genetic variation, and thus the parameter of genetic diversity $\left(H_{\mathrm{E}}\right)$ is more appropriate.

This study was the first to use ISSR markers to evaluate genetic diversity in $C$. tetradenius plants. According to the Jaccard's similarity index, none of the studied plants is genetically identical, which indicates that the resolution level was sufficient to distinguish all genotypes (Silva et al., 2013). CTE210 and CTE305 showed greater genetic similarity (0.76), while CTE105 showed low similarity index $(<0.16)$ with all related individuals.

High similarity indices suggest that individuals have a closer genetic relationship between each other, while lower indices reveal greater genetic distance (Sayed et al., 2009).

Probably, great genetic proximity occurs between the individuals of this population (Poço Redondo, Serra da Guia). Clusters III, IV, V, and VI are individually represented by the genotypes CTE105 (Lagarto, Tiradentes village), CTE107 (Lagarto, Tiradentes village), CTE203 (Porto da Folha, Lagoa do Rancho village), and CTE401 (Lagarto, Antônio Conselheiro village), respectively (Figure 2).

These genotypes have wide genetic variability, being, therefore, more divergent when compared with the other individuals. These results can be used in breeding and conservation programs of the species, and for commercial purposes.

The genetic structure of plant populations involves interactions of several distinct processes, such as habitat fragmentation and/or population isolation, changes in distribution, mutation, reproductive isolation, genetic drift, gene flow, selection, among others (Schaal et al., 1998; Thendral Hepsibha et al., 2010).

The separation of the 40 C. tetradenius individuals into six distinct clusters confirms the results obtained by AMOVA, which revealed greater genetic diversity within than between the studied populations.

The genetic study of natural populations allows the evaluation and quantification of genetic variability and its distribution in time and space. Thus, the greater the genetic variability in the population, the greater is the chance of perpetuation of the species. Besides, the characterization of the variability between and within natural populations allows the implementation of conservation strategies (Estopa et al., 2006).

ISSR markers have demonstrated their efficiency in the study of genetic variability for several other species. Lira Neto (2011) evaluated five DAF primers and six ISSR primers in 40 accessions from 27 Croton species, resulting in 186 bands produced by the ISSR marker, all of which were polymorphic. However, the number of primers must be increased to consolidate the clustering of the species.

Brito et al. (2016) studied the genetic diversity between Varronia curassavica accessions, using 14 primers, and obtained 149 bands with $97.98 \%$ polymorphism, Shannon index of $0.42, H_{\mathrm{E}}$ of 0.27 ; values close to the ones found in the present study. Rocha et al. (2016), when evaluating 41 Croton heliotropiifolius individuals, used 18 RAPD primers,

Genetics and Molecular Research 16 (2): gmr16029602 
which is also a dominant marker, and 15 ISSR primers, totaling 137 bands, of which 73 bands were produced by RAPD markers, and 64 bands were produced by ISSR markers, and the diversity found is relatively high. Soares et al. (2016) genetically characterized individuals from 10 Hancornia speciosa populations using 15 primers, generating 162 fragments with $100 \%$ polymorphism.

The authors state that genetic diversity among populations (77\%) was higher than within the populations $(23 \%)$, unlike the present study.

The flow between individuals may occur by pollinators and seed dispersers; thus, the knowledge on the seed pollination and dispersal mechanisms is important (Rocha et al., 2016). In addition, the knowledge of the reproduction system of the species of interest is fundamental, since this characteristic can influence the genetic variability, both by homogenizing and by increasing the divergence between individuals and populations (Zanella et al., 2012).

Genetic variation and genetic relationships were efficiently determined using the ISSR markers. Knowledge on the genetic diversity of the selected individuals is of ultimate importance, since it contributes to the information on the species and allows the selection of genotypes to be included in future conservation programs. Thus, the most divergent genotypes can be selected, as well as the most similar, according to the research interest.

The results of this study will help the research group to select plants for a collection of $C$. tetradenius in the germplasm bank of medicinal and aromatic plants of the Federal University of Sergipe.

\section{Conflicts of interest}

The authors declare no conflict of interests.

\section{ACKNOWLEDGMENTS}

The authors thank CNPq, FAPITEC/SE, CAPES, FINEP, and RENORBIO for their financial support of this study.

\section{REFERENCES}

Aghaei M, Darvishzadeh R and Hassani A (2012). Molecular characterization and similarity relationships among Iranian basil (Ocimum basilicum L.) accessions using inter simple sequence repeat markers. Rev. Cienc. Agron. 43: 312-320. http://dx.doi.org/10.1590/S1806-66902012000200014

Alves M, Araújo MFL, Gusmão GLS, Lira-Neto AC, et al. (2012). The genus Croton (Euphorbiaceae) in North-Eastern Brazil: diversity, uses and priorities for conservation. In: Medicinal Plants: Biodiversity and Drugs (Rai M, Cordell GA, Martinez JL, Marinoff M, et al., eds.). 1st edn. CRC Press, New York.

Alzate-Marin AL, Guidugli MC, Soriani HH, Martinez CA, et al. (2009). An efficient and rapid DNA minipreparation procedure suitable for PCR/SSR and RAPD analyses in tropical forest tree species. Braz. Arch. Biol. Technol. 5: 1217-1224 http://dx.doi.org/10.1590/S1516-89132009000500020.

Bertoni BW, de C Telles MP, Malosso MG, Torres SCZ, et al. (2010). Genetic diversity in natural populations of Jacaranda decurrens Cham. determined using RAPD and AFLP markers. Genet. Mol. Biol. 33: 532-538. http:// dx.doi.org/10.1590/S1415-47572010005000068

Blank AF, Almeida CS, Alves RP, Sampaio TS, et al. (2017). Formulação fungicida à base de óleo essencial de Croton tetradenius para controlar ou eliminar o fitopatógeno Fusarium solani. Patent BR-10-2017-000272-1. Instituto Nacional da Propriedade Industrial, Rio de Janeiro.

Borba RS, Garcia MAS, Kovalleski A, Oliveira AC, et al. (2005). Dissimilaridade genética de linhagens de Trichogramma Westwood (Hymenoptera: Trichogrammatidae) através de marcadores moleculares ISSR. Neotrop. Entomol. 34:

Genetics and Molecular Research 16 (2): gmr16029602 
565-569. http://dx.doi.org/10.1590/S1519-566X2005000400005

Brito FA, Nizio DAC, Silva AVC, Diniz LEC, et al. (2016). Genetic diversity analysis of Varronia curassavica Jacq. accessions using ISSR markers. Genet. Mol. Res. 15: 1-10 http://dx.doi.org/10.4238/gmr.15038681.

Carneiro-Torres DS (2009). Diversidade de Croton L. (Euphorbiaceae) no bioma Caatinga. Doctoral dissertations, Universidade Estadual de Feira de Santana, Feira de Santana. Available at [http://www2.uefs.br/ppgbot/pdf dissertacoes_teses/doutorado/2009/Carneiro-Torres2009_Tese_Doutorado.pdf].

Cruz CD (2001). Programa GENES: aplicativo computacional em genética e estatística. Ed. UFV, Viçosa.

Doyle JJ and Doyle JL (1990). Isolation of plant DNA from fresh tissue. Focus 12: 13-15.

Estopa RA, Souza AM, Moura MCO, Botrel MCG, et al. (2006). Diversidade genética em populações naturais de candeia (Eremanthus erythropappus (DC) Macleish). Sci. Forum 70: 97-106.

Fontenelle ROS, Morais SM, Brito EHS, Brilhante RSN, et al. (2008). Antifungal activity of essential oils of Croton species from the Brazilian Caatinga biome. J. Appl. Microbiol. 104: 1383-1390. http://dx.doi.org/10.1111/j.13652672.2007.03707.x

Giustina LD, Luz LN, Vieira FS, Rossi FS, et al. (2014). Population structure and genetic diversity in natural populations of Theobroma speciosum Willd. Ex Spreng (Malvaceae). Genet. Mol. Res. 13: 3510-3519 http://dx.doi. org/10.4238/2014.February.14.5.

González A, Coulson M and Brettell R (2002). Development of DNA markers (ISSRs) in mango. Acta Hortic. 575: 139143. http://dx.doi.org/10.17660/ActaHortic.2002.575.13

Jaccard P (1908). Nouvelles recherches sur la distribution florale. Bull. Soc. Vaud. Sci. Nat. 44: 223-270.

Khan S and Shah RA (2016). Assessment of genetic diversity among India Ginseng, Withania somnifera (L) Dunal using RAPD and ISSR markers. Res. Biotechnol. 7: 01-10.

Lira Neto AC (2011). Caracterização genética de espécies de Croton (Euphorbiaceae) ocorrentes no Nordeste Brasileiro. Doctoral dissertations, Universidade Federal de Pernambuco, Recife. Available at [http://repositorio.ufpe.br/ handle/123456789/2198].

Liu C, Xue GP, Cheng B, Wang X, et al. (2015). Genetic diversity analysis of Capparis spinosa L. populations by using ISSR markers. Genet. Mol. Res. 14: 16476-16483 http://dx.doi.org/10.4238/2015.December.9.19.

Lucena MFA (2009). Diversidade de Euphorbiaceae (s.1.) no Nordeste do Brasil. Doctoral dissertations. Universidade Federal de Pernambuco, Recife. Available at [http://repositorio.ufpe.br/handle/123456789/722].

Nei M (1987). Molecular Evolutionary Genetics. Columbia University Press, New York.

Peakall R and Smouse PE (2012). GenAlEx 6.5: genetic analysis in Excel. Population genetic software for teaching and research - an update. Bioinformatics 28: 2537-2539. http://dx.doi.org/10.1093/bioinformatics/bts460

Rocha TO, Freitas JS, Santos ESL, Scaldaferri MM, et al. (2016). Estimate of genetic diversity in cassutinga (Croton heliotropiifolius) based on molecular markers. Afr. J. Biotechnol. 15: 518-523. http://dx.doi.org/10.5897/ AJB2015.15009

Rohlf FJ (2001). NTSYSpc: numerical taxonomy system, Version 2.0. Exeter Publishing, Setauket.

Sandes SS, Zucchi MI, Pinheiro JB, Bajay MM, et al. (2016). Molecular characterization of patchouli (Pogostemon spp) germplasm. Genet. Mol. Res. 15: 2-12 http://dx.doi.org/10.4238/gmr.15017458.

Santos RC, Queiroz CM, Batista VGL, Silva CRC, et al. (2013). Variabilidade de progênies F2 de amendoim geradas por meio de seleção de genitores ISSR-divergentes. Rev. Cienc. Agron. 44: 578-586. http://dx.doi.org/10.1590/S1806$\underline{66902013000300021}$

Sayed MH, Mohammad SBS and Ramisah MS (2009). Analysis of random amplified polymorphic DNA (RAPD) of Artemisia capillaris (Wormwood capillary) in east coast of peninsular Malaysia. World Appl. Sci. J. 6: 976-986.

Scaldaferri MM, Freitas JS, Vieira JGP, Gonçalves ZS, et al. (2014). Comparison of methods for estimates of molecular genetic diversity in genus Croton: influence of coefficients, clustering strategies and data projection. Genet. Mol. Res. 13: 5566-5573 http://dx.doi.org/10.4238/2014.July.25.11.

Schaal BA, Hayworth DA, Olsen KM, Rauscher JT, et al. (1998). Phylogeographic studies in plants: problems and prospects. Mol. Ecol. 7: 465-474.

Silva AVC, Rabbani ARC, Sena-Filho JG, Almeida CS, et al. (2012). Genetic diversity analysis of mangaba (Hancornia speciosa Gomes), an exotic Brazilian tropical species. Trop. Subtrop. Agroecosyst. 15: 217-225.

Silva AVC, Rabbani ARC, Almeida CS and Clivati D (2013). Genetic structure and diversity of the neem germplasm bank from Brazil Northeast. Afr. J. Biotechnol. 12: 2822-2829.

Silva AVC, Muniz EN, Almeida CS, Vitória MF, et al. (2015). Genetic diversity and sex identification in Genipa americana L. Trop. Subtrop. Agroecosyst. 18: 81-86.

Silva JS, Sales MF and Carneiro-Torres DS (2009). O gênero Croton (Euphorbiaceae) na microrregião do Vale do Ipanema, Pernambuco, Brasil. Rodriguésia 60: 879-901.

Genetics and Molecular Research 16 (2): gmr16029602 
Soares ANR, Vitória MF, Nascimento ALS, Ledo AS, et al. (2016). Genetic diversity in natural populations of mangaba in Sergipe, the largest producer State in Brazil. Genet. Mol. Res. 15: 1-12 http://dx.doi.org/10.4238/gmr.15038624.

Souza DCL (2015). Técnicas moleculares para caracterização e conservação de plantas medicinais e aromáticas: uma revisão. Rev. Bras. Pl. Med 17: 495-503. http://dx.doi.org/10.1590/1983-084X/13 071

Souza EMS, Pereira GS, Silva-Mann R, Álvares-Carvalho SV, et al. (2016). A comparative framework of the Erythrina velutina tree species in reforested land and native populations. Genet. Mol. Res. 15: 2-11 http://dx.doi.org/10.4238/ gmr.15028534.

Souza-Sobreira FB, Souza GB, Rosado CCG, Miranda FD, et al. (2015). Genetic diversity in three natural populations of Pitcairnia flammea (1.) John (Bromeliaceae) estimated by ISSR markers. Genet. Mol. Res. 14: 15892-15901 http:// dx.doi.org/10.4238/2015.December.3.1.

Tabin S, Kamili AN, Ganie SA, Zargar O, et al. (2016). Genetic diversity and population structure of Rheum species in Kashmir Himalaya based on ISSR markers. Flora 223: 121-128 http://dx.doi.org/10.1016/j.flora.2016.05.001.

Thendral Hepsibha B, Premalakshmi V and Sekar T (2010). Genetic diversity in Azima tetracantha (Lam) assessed through RAPD analysis. Indian J. Sci. Technol. 3: 170-173.

Trieu LN, Mien NT, Tien TV, Ket NV, et al. (2016). Genetic diversity of Panax stipuleanatus Tsai in North Vietnam detected by inter simple sequence repeat (ISSR) markers. Biotechnol. Biotechnol. Equip. 30: 506-511 http://dx.doi. org/10.1080/13102818.2016.1157448.

Webster GL (1993). A provisional synopsis of the sections of the genus Croton (Euphorbiaceae). Taxon 42: 793-823. http:// dx.doi.org/10.2307/1223265

Zanella CM, Janke A, Palma-Silva C, Kaltchuk-Santos E, et al. (2012). Genetics, evolution and conservation of Bromeliaceae. Genet. Mol. Biol. 35 (4 (suppl)): 1020-1026. http://dx.doi.org/10.1590/S1415-47572012000600017

Zietkiewicz E, Rafalski A and Labuda D (1994). Genome fingerprinting by simple sequence repeat (SSR)-anchored polymerase chain reaction amplification. Genomics 20: 176-183. http://dx.doi.org/10.1006/geno.1994.1151

Genetics and Molecular Research 16 (2): gmr16029602 